\title{
Adrenomedullin in plasma of surgical ICU- patients with sepsis - a pilot study
}

\author{
T-P Simon ${ }^{1 *}$, S Doemming ${ }^{1}$, A Humbs ${ }^{1}$, L Martin', C Bruells ${ }^{1}$, O Hartmann², J Struck², A Bergmann², G Marx , \\ T Schuerholz $^{1}$
}

From ESICM LIVES 2015

Berlin, Germany. 3-7 October 2015

\section{Introduction}

Synthesis and liberation of adrenomedullin (ADM) are found in different tissues and endothelial cells and ADM is induced by hypoxia, oxidative stress, and proinflammatory cytokines [1]. The prognostic value of $\mathrm{ADM}$ is described in general patient populations, in medical patients and in particular recently in patients with suspected sepsis in the emergency department $[2,3]$. In surgical patients, the obstacle is to differentiate between postoperative inflammation and sepsis and to assess the patients' prognosis.

\section{Objectives}

To evaluate the value of measuring ADM in surgical ICU-patients with sepsis, severe sepsis or septic shock.

\section{Methods}

In a prospective, observational clinical trial, we included 42 consecutive ICU patients after major surgery with clinical signs of sepsis according to the ACCP/SCCM definitions and 14 patients admitted routinely to the ICU after major surgery. Plasma samples to determine ADM were drawn within 16 hours after diagnosis of sepsis or routine admission. Laboratory and clinical parameters and 28-day and 90-day mortality were recorded. Values are expressed as median and interquartile ranges (IQR), or counts and percentages as appropriate. Group comparisons of continuous variables were performed using Kruskal-Wallis test. Biomarker data were log-transformed. Spearman rank-order correlation was applied to continuous variables. A p-value of $<0.05$ was considered significant.

'University Hospital RWTH Aachen, Department of Intensive Care and Intermediate Care, Aachen, Germany

Full list of author information is available at the end of the article

\section{Results}

Patients (66\% male) were 70 (IQR 60.5-77) years old and had a body mass index of 26.2 (IQR $24.2-29.4) \mathrm{kg} / \mathrm{m}^{2}$. Lengths of stay (LOS) in ICU was 3 (IQR 1-12) days and in hospital 16.5 (IQR 8-21) days. Of the 42 consecutive ICU patients, eight patients had sepsis, 19 developed severe sepsis and 15 suffered from septic shock. ADM increased with severity $(\mathrm{p}<0.0001$, table 1$)$.

Adrenomedullin (ADM) levels in control, sepsis, severe sepsis and septic shock patients $(\mathrm{p}<0.0001)$. Post-hoc comparisons show significant differences between controls and severe sepsis/septic shock, as well as sepsis and severe sepsis/septic shock.

Higher ADM concentrations were associated with poor 90 day outcome $(p=0.019$, figure 1$)$ and more frequent vasopressor usage $(\mathrm{p}=0.001$, figure 2$)$

\section{Conclusions}

Adrenomedullin levels are increased according to the severity of sepsis in surgical ICU patients. Higher levels of adrenomedullin predict the need of vasopressor and survival. Thus, adrenomedullin may be a useful additional parameter in surgical patients with suspected sepsis.

\section{Grant Acknowledgment}

This study was supported by a restricted grant of Sphingotec, Henningsdorf, Germany.

Table 1 ADM concentrations in all groups

\begin{tabular}{llll}
\hline Subgroup & $\mathbf{n}$ & Median $(\mathbf{p g} / \mathbf{m L})$ & IQR $(\mathbf{p g} / \mathbf{m L})$ \\
\hline Control & 14 & 16.2 & $11.8-20.0$ \\
\hline Sepsis & 8 & 25.8 & $20.3-40.2$ \\
\hline Severe sepsis & 19 & 84.2 & $42.7-118.5$ \\
\hline Septic shock & 15 & 119.7 & $83.8-172.6$ \\
\hline
\end{tabular}



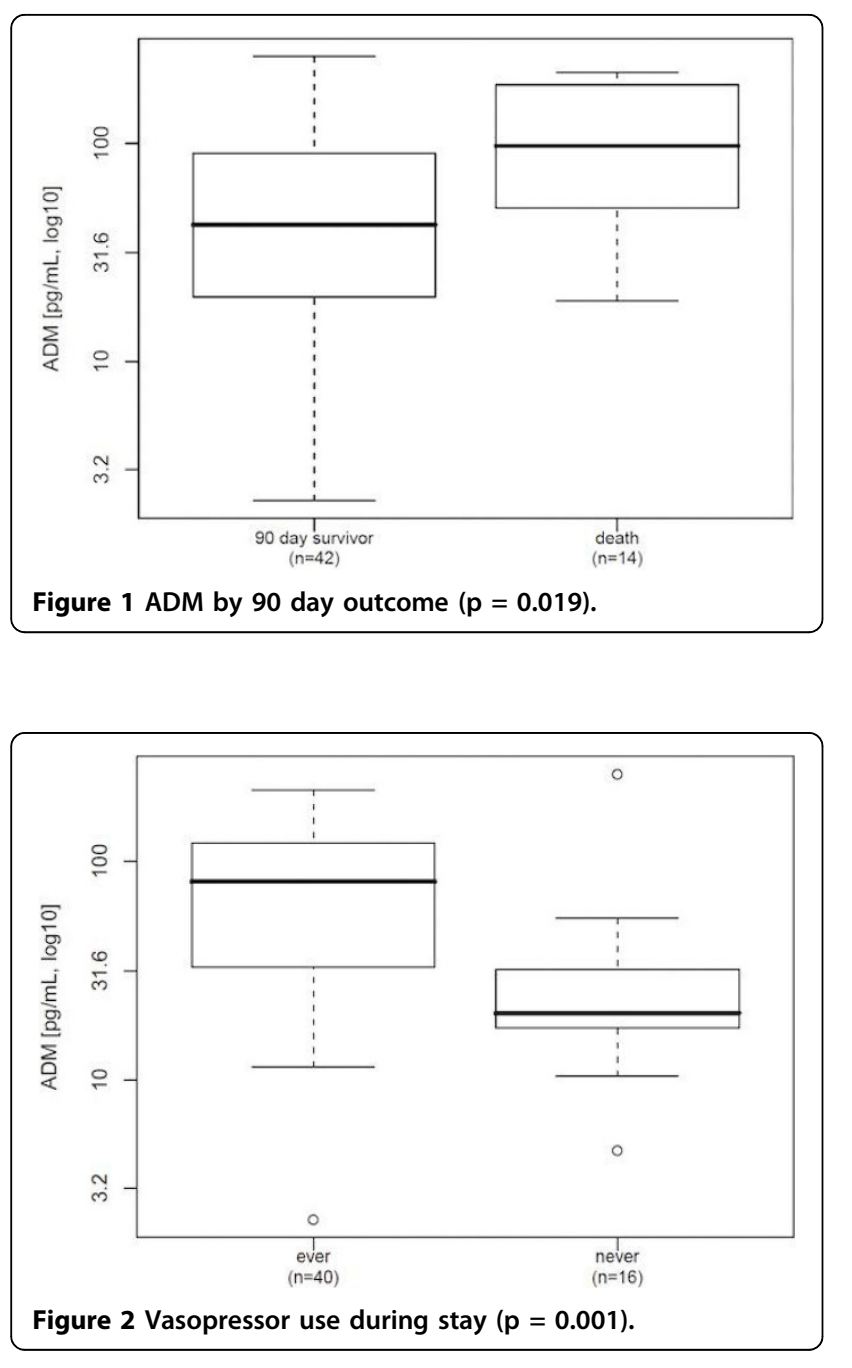

\section{Authors' details}

'University Hospital RWTH Aachen, Department of Intensive Care and Intermediate Care, Aachen, Germany. ${ }^{2}$ Sphingotec GmbH, Hennigsdorf, Germany.

Published: 1 October 2015

\section{References}

1. Ueda S, et al: American journal of respiratory and critical care medicine 1999, 160:132.

2. Chen YX, et al: The American journal of emergency medicine 2013, 31:1017.

3. Marino R, et al: Critical Care 2014, 18:R34.

doi:10.1186/2197-425X-3-S1-A302

Cite this article as: Simon et al:: Adrenomedullin in plasma of surgical

ICU-patients with sepsis - a pilot study. Intensive Care Medicine

Experimental 2015 3(Suppl 1):A302.

\section{Submit your manuscript to a SpringerOpen ${ }^{\circ}$ journal and benefit from:}

- Convenient online submission

- Rigorous peer review

- Immediate publication on acceptance

- Open access: articles freely available online

- High visibility within the field

- Retaining the copyright to your article

Submit your next manuscript at $\gg$ springeropen.com 